\title{
PENGARUH REWARD DAN PUNISHMENT TERHADAP KINERJA KARYAWAN DENGAN MOTIVASI SEBAGAI VARIABEL INTERVENING (STUDI KASUS PADA PT. BANK CENTRAL ASIA TBK.)
}

\author{
Natasya Michelle Putri Kentjana ${ }^{1}$, Piter Nainggolan ${ }^{2}$ \\ ${ }^{1}$ Akuntansi, Universitas Bunda Mulia, Jakarta,natasyamichelleee@gmail.com \\ ${ }^{2}$ Akuntansi, Universitas Bunda Mulia, Jakarta, pnainggolan@bundamulia.ac.id
}

\begin{abstract}
ABSTRAK
Masalah sumber daya manusia masih menjadi sorotan utama bagi perusahaan untuk dapat bertahan dalam ketatnya persaingan bisnis di era globalisasi. Keberhasilan perusahaan dalam mencapai tujuan dipengaruhi oleh beberapa faktor, salah satu faktor penting adalah sumber daya manusia. Setiap perusahaan pasti memiliki visi, misi, dan tujuan yang ingin dicapai. Namun setiap individu sebagai sumber daya manusia dalam suatu perusahaan biasanya juga memiliki kepentingan atau tujuan pribadi. Sering kali tujuan pribadi karyawan tidak selaras dengan tujuan perusahaan. Ketidakselarasan tujuan perusahaan dan tujuan pribadi karyawan akan mengakibatkan tujuan perusahaan tersebut tidak tercapai. Untuk itu diperlukan suatu pengendali kerja yang dapat merencanakan, mengarahkan, mengamati, melaksanakan, dan mengevaluasi sehingga meningkatkan kemungkinan tercapainya tujuan perusahaan. Sistem ini biasa disebut sistem pengendalian manajemen (Management Control System).

Penelitian ini bertujuan untuk mengetahui apakah unsur reward dan punishment berpengaruh terhadap kinerja karyawan serta apakah dengan adanya motivasi mampu memediasi reward dan punishment terhadap kinerja karyawan agar menjadi lebih baik atau sebaliknya pada perusahaan. Penelitian ini bertujuan untuk mengetahui pengaruh reward dan punishment terhadap kinerja karyawan serta untuk mengetahui apakah motivasi mampu memediasi reward dan punishment terhadap kinerja karyawan agar menjadi lebih baik atau sebaliknya pada perusahaan. Populasi penelitian ini adalah seluruh karyawan tetap PT. Bank Central Asia (BCA). Data yang diperoleh adalah data primer melalui kuesioner yang disebarkan pada karyawan tetap BCA. Data dianalisis dengan metode Structural Equation Model-Partial Least Square (SEM-PLS) dengan 50 sampel data penelitian yang dikumpulkan dengan teknik proportional sampling. Software yang digunakan untuk menganalisis data adalah WarpPLS 3.0.

Hasil penelitian menunjukan bahwa reward memiliki pengaruh yang tidak signifikan terhadap kinerja karyawan, sedangkan punishment berpengaruh signifikan terhadap kinerja karyawan. Selain itu reward tidak berpengaruh signifikan terhadap motivasi namun punishment berpengaruh signifikan terhadap motivasi. Kesimpulan mediasi menunjukkan bahwa motivasi mampu memediasi punishment terhadap kinerja karyawan namun motivasi tidak memediasi reward terhadap kinerja karyawan.
\end{abstract}

Kata Kunci: Reward, Punishment, Motivasi, Kinerja Karyawan, Management Control System. 


\title{
National Conference of Creative Industry: \\ Sustainable Tourism Industry for Economic Development
}

Universitas BundaMulia, Jakarta, 5-6 September 2018

e-ISSN No: 2622 - 7436

\begin{abstract}
Human resources problem is still the main highlight for company in order to survive the tight of business competition in globalization era. Success of the company in achieving goals affected by various factor. One of the important factor is human resources, every company definitely has vision, mission, and the goal they want to achieve, however every individual as human resources in a company usually also have interests or personal goals. Often employees personal goals not in harmony with the company goals. Not in harmony of the company goals and employees personal goals will cause the company not achieved the company goals, therefor it takes a work controller that can, planed,directed ,observed, implemented, and evaluated so that increases the possibilities of achieving company goals, this system usually called management control system (MCS)

This study aims to determine the effect of reward and punishment on employees performance and to determine whether the motivation is able to mediate rewards and punishment on employee performance to be better or the opposite at the company. The population of this study is all permanent employees of PT. Bank Central Asia (BCA). The data obtained are primary data through questionnaires distributed to BCA permanent employees. Data were analyzed using Structural Equation Model-Partial Least Square (SEM-PLS) method with 50 samples of research data collected by proportional sampling technique. The software used to analyze data is WarpPLS 3.0.

The results showed that rewards has a non-significant effect on employee performance, while punishment has a significant effect on employee performance. In addition rewards has no significant effect on motivation but punishment has a significant effect on motivation. The conclusion of mediation shows that motivation is able to mediate punishment on employee performance but motivation does not mediate reward on employee performance.
\end{abstract}

Keywords: Reward, Punishment, Motivation, Employees Performance, Management Control System.

\section{PENDAHULUAN}

Dewasainiekonomiberkembangdenganpesatdiiringidenganperkembanganilmupenge tahuan dan teknologi yang menuntutsumberdayamanusiauntukmengikutiperubahan yang ada. Seiringperkembanganekonomi yang tinggimakasemakintinggi pula persaingandalam dunia usaha. Masalah sumber daya manusia masih menjadi sorotan utama bagi perusahaan untuk dapat bertahan dalam ketatnya persaingan bisnis di era globalisasi. Keberhasilan perusahaan dalam mencapai tujuan dipengaruhi oleh beberapa faktor, salah satu faktor penting adalah sumber daya manusia. Walaupun didukung dengan sarana dan prasarana serta sumber daya alam yang memadai, tetapi tanpa dukungan sumber daya manusia yang berkualitas kegiatan perusahaan tidak akan terselesaikan dengan baik. Hal ini menunjukan bahwa sumber daya manusia merupakan kunci pokok yang harus diperhatikan dengan segala kebutuhannya, mengingat sumber daya manusia merupakan pelaku dari keseluruhan tingkat perencanaan sampai dengan evaluasi yang mampu memanfaatkan sumber daya-sumber daya lainnya yang dimiliki oleh perusahaan.

Setiap perusahaan pasti memiliki visi, misi, dan tujuan yang ingin dicapai. Begitu juga setiap individu sebagai sumber daya manusia dalam suatu perusahaan biasanya 


\section{National Conference of Creative Industry: \\ Sustainable Tourism Industry for Economic Development}

Universitas BundaMulia, Jakarta, 5-6 September 2018 e-ISSN No: 2622 - 7436

memiliki kepentingan atau tujuan pribadi. Sering kali tujuan pribadi karyawan tidak selaras dengan tujuan perusahaan. Ketidakselarasan tujuan perusahaan dan tujuan pribadi karyawan akan mengakibatkan tujuan perusahaan tersebut tidak tercapai. Untuk itu diperlukan suatu pengendali kerja yang dapat merencanakan, mengarahkan, mengamati, melaksanakan, dan mengevaluasi sehingga meningkatkan kemungkinan tercapainya tujuan perusahaan. Sistem ini biasa disebut sistem pengendalian manajemen (Management Control System).

Sistem pengendalian manajemen dapat dimanfaatkan untuk memotivasi seluruh pekerja dalam perusahaan guna mewujudkan tujuan perusahaan melalui perilaku yang diharapkan. Sistem pengendalian manajemen ini akan melibatkan seluruh alat dan sistem yang digunakan suatu perusahaan untuk memastikan bahwa perilaku dan keputusan para pekerjanya konsisten dengan tujuan dan strategi perusahaan. Jika dirancang dengan baik, sistem pengendalian manajemen ini akan memengaruhi perilaku karyawan dimana akan meningkatkan probabilitas suatu perusahaan akan mencapai tujuannya. Sistem pengendalian manajemen dapat berupa pengendalian hasil, pengendalian personel, dan pengendalian tindakan.

Menurut Pratheepkanth (2011) perusahaan diharapkan mampu mempertahankan karyawannya yang berkualitas serta menjaga mereka agar dapat terus termotivasi, salah satunya dengan menetapkan suatu sistem atau strategi tertentu untuk memberikan keseimbangan antara kontribusi yang diharapkan dengan apa yang telah diberikan dalam bentuk imbalan atau penghargaan tertentu. Dalam sistem pengendalian manajemen, hal ini berkaitan dengan pengendalian hasil. Pengendalian hasil berarti melibatkan pemberian imbalan pada karyawan untuk hasil yang memuaskan. Pemberian reward dan punishment adalah salah satu contoh dari pengendalian hasil karena melibatkan pemberian imbalan pada karyawan untuk hasil yang memuaskan.

Melalui reward dan punishment diharapkan karyawan akan menjadi lebih berkualitas dan bertanggung jawab dengan tugas yang diberikan. Reward dan punishment adalah dua kata yang saling bertolak belakang akan tetapi, kedua hal tersebut saling berkaitan, keduanya memotivasi karyawan untuk meningkatkan kualitas kinerja. Oleh sebab itu sistem reward dan punishment dalam sistem pengendalian manajemen penting untuk meningkatkan motivasi karyawan mencapai prestasi yang terbaik. Dengan pengendalian hasil yang baik, perusahaan tidak perlu mendikte karyawan terkait apa yang harus dilakukan atau diputuskan, karena pengendalian hasil ini memengaruhi tindakan atau keputusan yang membuat karyawan lebih memperhatikan konsekuensi tindakan atau keputusan yang mereka buat. Kekeliruan dalam menerapkan sistem ini akan berakibat timbulnya demotivasi dan tidak adanya kepuasan kerja dikalangan karyawan dan apabila hal tersebut terjadi dapat menyebabkan rendahnya kinerja baik karyawan maupun perusahaan.

Banyak faktor-faktor yang dapat memengaruhi kinerja seorang karyawan, namun dalam penelitian ini peneliti hanya berfokus pada reward dan punishment yang diterima karyawan sebagai variabel bebas dan motivasi karyawan terhadap kinerja karyawan sebagai variabel mediasi. Penelitian menurut Ratri, et al. (2017) menyimpulkan bahwa reward dan punishment berpengaruh positif dan signifikan terhadap kinerja karyawan di PT. INTI (Persero) Bandung. Subjek dari penelitian ini yaitu 51 orang karyawan pada Divisi Corporate Services PT. INTI (Persero) Bandung. Hasil yang didapatkan dari penelitian menunjukkan bahwa reward dan punishment dapat mengatasi motivasional karyawan dalam bekerja serta menciptakan keberlangsungan operasional perusahaan. 


\section{National Conference of Creative Industry: \\ Sustainable Tourism Industry for Economic Development}

Universitas BundaMulia, Jakarta, 5-6 September 2018

e-ISSN No: 2622 - 7436

Penelitian ini mengambil objek penelitian pada PT. Bank Central Asia Tbk. (BCA) yang telah menjadi salah satu bank terbesar di Indonesia, sesuai dengan visinya untuk menjadi bank pilihan utama andalan masyarakat yang berperan sebagai pilar penting perekonomian Indonesia. BCA menghargai sumber daya manusia yang ada sebagai aset dan modal utama keberhasilan perusahaan dalam menghadapi persaingan industri perbankan yang semakin kompetitif. BCA berkomitmen untuk menghasilkan sumber daya manusia yang profesional dan berkualitas tinggi, karena sumber daya manusia yang berkualitas merupakan aspek penting dalam mempertahankan keunggulan kompetitif dan mendukung strategi bisnis BCA. Penelitian ini bertujuan untuk mengetahui pengaruh reward dan punishment terhadap kinerja karyawan serta untuk mengetahui apakah motivasi mampu memediasi reward dan punishment terhadap kinerja karyawan agar menjadi lebih baik atau sebaliknya pada BCA. Diharapkan penelitian ini dapat menghasilkan informasi yang bermanfaat sebagai masukan dan pertimbangan bagi perusahaan untuk mengetahui dampak dari sistem reward dan punishment dalam meningkatkan motivasi karyawan dalam bekerja, sehingga perusahaan dapat mengevaluasi dan meningkatkan sistem pengendalian manajemen dalam hal reward dan punishment.

\section{TINJAUAN PUSTAKA}

Sumarsan (2013) menyatakan bahwa sistem pengendalian manajemen adalah suatu rangkaian tindakan dan aktivitas yang terjadi pada seluruh kegiatan organisasi dan berjalan secara terus menerus. Sistem pengendalian manajemen didesain untuk meningkatkan kinerja perusahaan (Jamil \& Mohamed, 2013). Menurut Aliyu, et al. (2014) sistem pengendalian manajemen berperan untuk mempengaruhi dan mengarahkan perilaku sumber daya organisasi agar sesuai dengan tujuan perusahaan. Sistem pengendalian manajemen merupakan kesatuan sistem lengkap seperti aturan manajerial dalam mengarahkan karyawan, sistem, aturan, praktik, nilai, dan pengelolaan kegiatan lain yang dilakukan dengan menggunakan informasi agar pelaku karyawan dapat dikendalikan untuk keselarasan tujuan. Menurut Merchant dan Stede (2014) terdapat tiga elemen dalam mengukur sistem pengendalian manajemen, yaitu pengendalian hasil, pengendalian personel, dan pengendalian tindakan.Pengendalian hasil adalah pengendalian yang memberi informasi pada karyawan apa yang diharapkan dari mereka dan mendorong mereka untuk melakukan tindakan yang dapat mengeluarkan hasil yang diinginkan. Pengendalian hasil melibatkan suatu penghargaan individu untuk suatu kinerja yang baik atau menghukum mereka untuk kinerja yang buruk. Pemberian reward dan punishment merupakan contoh dari pengendalian hasil.

Menurut Handoko (2012)reward merupakan bentuk apresiasi usaha untuk mendapatkan tenaga kerja yang profesional sesuai dengan tuntutan jabatan diperlukan suatu usaha kegiatan pengorganisasian, perencanaan, penggunaan, dan pemeliharaan tenaga kerja agar mampu melaksanakan tugas dengan efektif dan efisien. Menurut Thompson (2002) dalam Nnaji-Ihedinmah dan Egbunike (2015) menekankan bahwa reward tidak hanya mencakup unsur kuantitatif seperti gaji, upah dan lain-lain, tetapi juga unsur lainnya yang berwujud bukan uang, seperti kesempatan untuk melaksanakan tanggung jawab yang lebih besar, peluang karir, kesempatan untuk belajar dan berkembang, kualitas kehidupan yang layak dalam organisasi dan lain-lain. NnajiIhedinmah dan Egbunike (2015) mendimensikan reward menjadi dua, yaitu intrinsic reward dan ekstrinsic reward. Intrinsic reward merupakan bagian dari pekerjaan itu 


\section{National Conference of Creative Industry: \\ Sustainable Tourism Industry for Economic Development}

Universitas BundaMulia, Jakarta, 5-6 September 2018

e-ISSN No: 2622 - 7436

sendiri, seperti tanggung jawab, tantangan, dan karakteristik umpan balik dari pekerjaan. Menurut Syahril, dan Nurbiyati (2016)intrinsic reward merupakan reward yang tidak memiliki wujud nyata, yang diterima karyawan untuk dirinya sendiri, biasanya reward ini merupakan nilai positif atau rasa puas karyawan terhadap dirinya sendiri karena pengakuan, tanggung jawab dan kesempatan belajar, yang semua itu merupakan kebutuhan psikologis karyawan. Sedangkan ekstrinsic reward biasanya mencakup kompensasi langsung, kompensasi tidak langsung dan manfaat lainnya. Penghargaan ini berbentuk finansial, material, atau sosial dari lingkungan. Menurut Syahril dan Nurbiyati (2016)ekstrinsic reward merupakan penghargaan yang memiliki wujud nyata, yang datang dari luar diri orang tersebut, bisa berupa finansial seperti gaji, bonus, tunjangan dan bisa pula berupa non-finansial seperti promosi.

Mangkunegara (2013)menjelaskan punishment adalah ancaman hukuman yang bertujuan untuk memperbaiki kinerja karyawan pelanggar, memelihara peraturan yang berlaku dan memberikan pelajaran kepada pelanggar. Pada dasarnya tujuan pemberian punishment adalah supaya karyawan yang melanggar merasa jera dan tidak akan mengulangi lagi kesalahan yang dilakukannya. Dalam perusahaan sanksi diberikan kepada karyawan yang lalai atau melakukan kesalahan yang dapat merugikan perusahaan. Jika reward adalah suatu bentuk yang positif, maka punishment adalah suatu bentuk yang negatif. Namun, apabila punishment diberikan secara tepat dan bijak dapat menjadi alat peransang pegawai untuk meningkatkan produktivitas atau disiplin kerjanya dalam Anwar dan Dunija (2016). Jenis-jenis punishment menurut Purwanto (2006) dalam penelitian Sunarto, et al.(2017) yaitu punishment preventif dan punishment represif. Punishment preventif bermaksud untuk mencegah agar tidak terjadi pelanggaran sehingga punishment preventif ini dilakukan sebelum pelanggaran terjadi. Sedangkan punishment represif dilakukan karena adanya kesalahan yang telah diperbuat. Oleh sebab itu, punishment ini dilakukan setelah terjadi pelanggaran atau kesalahan.

Reward dan punishment yang dirancang dengan baik berpeluang besar untuk meningkatkan motivasi sehingga dapat meningkatkan kinerja karyawan juga. Menurut Mangkunegara (2013) motivasi adalah kondisi atau energi yang menggerakkan diri karyawan yang terarah atau tertuju untuk mencapai tujuan organisasi perusahaan. Apabila individu termotivasi, mereka akan membuat pilihan yang positif untuk melakukan sesuatu, karena dapat memuaskan keinginan mereka. Pada dasarnya motivasi dapat memacu karyawan untuk bekerja keras sehingga dapat mencapai tujuan mereka. Hal ini akan meningkatkan produktivitas kerja karyawan sehingga berpengaruh pada pencapaian tujuan perusahaan. Menurut Mangkunegara (2013) kinerja karyawan adalah hasil kerja secara kualitas dan kuantitas yang dicapai oleh seorang karyawan dalam melaksanakan tugasnya sesuai dengan tanggung jawab yang diberikan kepadanya. Kinerja karyawan merupakan faktor penting dalam suatu organisasi, karena kinerja karyawan yang baik akan menghantarkan organisasi pada sebuah keberhasilan. Kinerja karyawan yang tinggi akan membantu organisasi untuk mencapai tujuan strategis sekaligus mempertahankan keunggulan kompetitif yang dimiliki.

\section{PENGEMBANGAN HIPOTESIS}

Model hipotesis yang digunakan dalam penelitian dapat dilihat pada gambar 1 : 


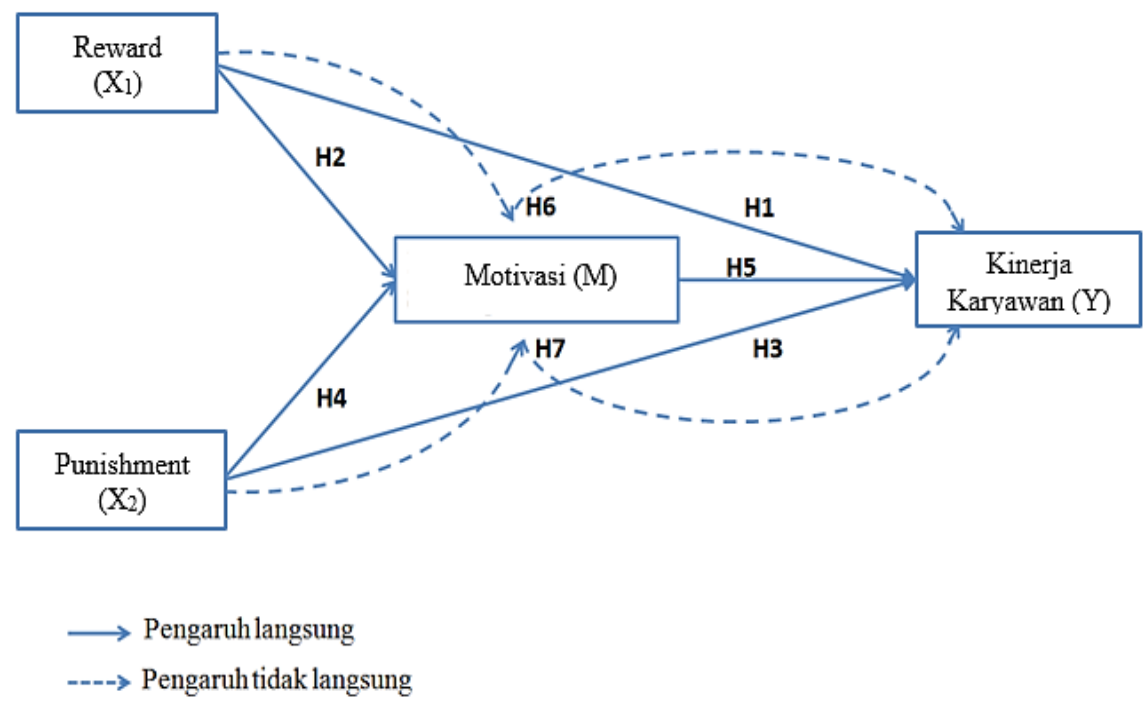

\section{Gambar 1. Model Hipotesis}

Sumber : Data Diolah(2018)

Reward dimunculkan untuk memotivasi seseorang supaya giat dalam menjalankan tanggung jawab karena terdapat anggapan bahwa dengan pemberian hadiah atas hasil pekerjaannya, karyawan akan lebih bekerja maksimal yang berarti akan meningkatkan kinerjanya. Pada dasarnya, reward dibutuhkan untuk merangsang karyawan agar meningkatkan kualitas kerjanya. Menurut Febrianti, et al. (2014) Sistem reward tersebut digunakan sebagai bentuk reaksi pimpinan terhadap kinerja yang ditunjukkan oleh karyawannya. Menurut penelitian yang dilakukan oleh Febrianti, et al.(2014)reward memiliki pengaruh positif signifikan terhadap kinerja karyawan. Berdasarkan hal tersebut, maka hipotesis pertama dalam penelitian ini adalah sebagai berikut :

\section{$H_{1}$ : Reward berpengaruh positif dan signifikan terhadap kinerja karyawan.}

Shields (2016)menyatakan reward adalah sesuatu yang berwujud atau tidak berwujud yang organisasi berikan kepada karyawan baik sengaja atau tidak sengaja sebagai imbalan atas potensi karyawan atau kontribusi atas pekerjaan yang baik, dan untuk karyawan yang menerapkan nilai positif sebagai pemuas kebutuhan tertentu. Menurut Merchant dan Stede (2016) sistem reward merupakan hal penting karena mendorong definisi area hasil yang diinginkan dan memotivasi karyawan untuk mencapai dan melebihi target kinerja. Menurut hasil penelitian yang dilakukan oleh Karami, et al. (2013) reward memiliki pengaruh positif signifikan terhadap motivasi. Berdasarkan hal tersebut, maka hipotesis kedua dalam penelitian ini adalah sebagai berikut :

\section{$\mathrm{H}_{2}$ : Reward berpengaruh positif dan signifikan terhadap motivasi.}

MenurutFebrianti, et al.(2014) punishment dibutuhkan untuk merangsang karyawan agar meningkatkan kualitas kerjanya. Sistem punishment tersebut digunakan sebagai bentuk reaksi pimpinan terhadap kinerja yang ditunjukkan oleh karyawannya. Berdasarkan pernyataan ini dapat disimpulkan bahwa punishment digunakan untuk memotivasi karyawan supaya kinerja dapat berjalan secara maksimal. Punishment diterapkan dengan tujuan memelihara peraturan yang berlaku agar segala tugas dan tanggung jawab dapat terlaksana dengan baik berdasarkan Suryadilaga, et al.(2016, p. 158). Menurut penelitian yang dilakukan oleh Suryadilaga, et 


\section{National Conference of Creative Industry: \\ Sustainable Tourism Industry for Economic Development}

Universitas BundaMulia, Jakarta, 5-6 September 2018

e-ISSN No: 2622 - 7436

al.(2016)punishmentmemiliki pengaruh signifikan terhadap kinerja karyawan. Berdasarkan hal tersebut, maka hipotesis ketiga dalam penelitian ini adalah sebagai berikut :

$\mathrm{H}_{3}$ : Punishment berpengaruh positif dan signifikan terhadap kinerja karyawan.

Menurut Febrianti, et al. (2014, p. 4) punishment dimunculkan bagi seorang karyawan yang melakukan kesalahan dan pelanggaran agar termotivasi untuk menghentikan perilaku menyimpang dan mengarahkan pada perilaku positif. Menurut penelitian yang dilakukan oleh Widyanti dan Sari (2014)punishment memiliki pengaruh signifikan terhadap motivasi. Berdasarkan hal tersebut, maka hipotesis keempat dalam penelitian ini adalah sebagai berikut :

\section{$\mathrm{H}_{4}$ : Punishment berpengaruh positif dan signifikan terhadap motivasi.}

Motivasi kerja menurut Hasibuan dalam Febrianti, et al. (2014) memiliki beberapa tujuan diantaranya mendorong gairah dan semangat kerja karyawan, meningkatkan moral dan kepuasan kerja karyawan, meningkatkan produktivitas kerja karyawan, mempertahankan loyalitas dan kestabilan karyawan perusahaan, meningkatkan kedisiplinan dan menurunkan tingkat absensi karyawan, mengefektifkan pengadaan karyawan, menciptakan suasana dan hubungan kerja yang baik, meningkatkan kreativitas dan partisipasi karyawan, meningkatkan tingkat kesejahteraan karyawan, mempertinggi rasa tanggung jawab karyawan terhadap tugas-tugasnya dan meningkatkan efisiensi penggunaan alat-alat dan bahan baku. Menurut penelitian yang dilakukan oleh Febrianti, et al. (2014) motivasi memiliki pengaruh signifikan terhadap kinerja karyawan. Berdasarkan hal tersebut, maka hipotesis kelima dalam penelitian ini adalah sebagai berikut :

\section{H5 : Motivasi berpengaruh positif dan signifikan terhadap kinerja karyawan}

Secara umum pemberian reward pada karyawan bertujuan untuk meningkatkan kinerja karyawan sehingga tujuan perusahaan dapat tercapai, selain itu dengan adanya reward, karyawan merasa kontribusi yang diberikan dihargai sehingga memacu kinerja karyawan menjadi semakin meningkat. Namun dalam penelitian yang dilakukan oleh Suak, et al. (2017) menyimpulkan bahwa tidak terdapat pengaruh langsung yang signifikan antara reward dan kinerja karyawan sehingga memungkinkan adanya pengaruh tidak langsung. Berdasarkan argumentasi diatas, maka hipotesis keenam yang dapat dirumuskan adalah :

H6 $_{6}$ : Reward berpengaruh positif dan signifikan terhadap kinerja karyawan dengan dimediasi oleh motivasi

Menurut Mangkunergara (2013) punishment merupakan ancaman hukuman yang bertujuan untuk memperbaiki karyawan pelanggar, memelihara peraturan yang berlaku dan memberikan pelajaran kepada pelanggar. Pelajaran tersebut nantinya dapat merubah sikap karyawan yang kurang baik menjadi lebih baik lagi sehingga berdampak pada kinerja karyawan yang lebih profitabel dan profesional. Secara umum pemberian punishment pada karyawan bertujuan untuk meningkatkan kinerja karyawan sehingga tujuan perusahaan dapat tercapai, selain itu dengan adanya punishment karyawan akan merasa lebih bertanggung jawab atas pekerjaan yang dibebankan kepadanya sehingga memacu kinerjanya semakin baik. Namun dalam penelitian yang dilakukan oleh Suak, et al. (2017) menyimpulkan bahwa tidak terdapat pengaruh langsung yang signifikan antara 


\section{National Conference of Creative Industry: \\ Sustainable Tourism Industry for Economic Development}

Universitas BundaMulia, Jakarta, 5-6 September 2018

e-ISSN No: 2622 - 7436

punishment dan kinerja karyawan sehingga memungkinkan adanya pengaruh tidak langsung. Berdasarkan argumentasi diatas, maka hipotesis ketujuh yang dapat dirumuskan adalah :

$\mathrm{H}_{7}$ : Punishment berpengaruh positif dan signifikan terhadap kinerja karyawan dengan dimediasi oleh motivasi

\section{METODE PENELITIAN}

\section{Populasi dan Sampel}

Menurut Sujarweni (2015) populasi adalah keseluruhan jumlah yang terdiri atas obyek atau subyek yang mempunyai karakteristik dan kualitas tertentu yang ditetapkan oleh peneliti untuk diteliti dan kemudian ditarik kesimpulannya. Populasi dalam penelitian ini adalah seluruh karyawan tetap PT. Bank Central Asia Tbk. Teknik pengambilan sampel yang digunakan adalah proportional sampling. Proportional sampling adalah salah satu teknik sampling non-random sampling dimana pengambilan sampel yang memperhatikan pertimbangan kategori dalam populasi penelitian. Kriteria yang digunakan untuk memilih sampel dalam penelitian ini yaitu responden harus merupakan karyawan tetap BCA. Sampel dalam penelitian ini adalah karyawan tetap BCA yang dipilih sebanyak 50 orang.

\section{Pengukuran Variabel Penelitian}

Menurut Wijanto (2008) dalam Jogiyanto (2015) variabel kunci yang menjadi perhatian adalah variabel laten (latent variable). Variabel laten ini hanya dapat diamati secara tidak langsung dan tidak sempurna melalui efeknya pada variabel teramati (observed variable). Variabel teramati adalah variabel yang dapat diamati atau diukur secara empiris dan sering disebut sebagai indikator. Variabel teramati merupakan efek atau ukuran dari variabel laten. Ada dua jenis variabel laten yaitu variabel independen yang dalam hal ini disebut variabel eksogen (exogenous) dan juga variabel dependen yang disebut variabel endogen (endogenous). Variabel eksogen (exogenous) adalah variabel yang mempengaruhi atau yang menjadi sebab perubahannya atau timbulnya variabel endogen (terikat). Sedangkan variabel endogen (endogenous) adalah variabel yang dipengaruhi atau yang menjadi akibat, karena adanya variabel bebas (Jogiyanto, 2015).

Variabel eksogen dalam penelitian ini yaitu :

1. Reward $\left(\mathrm{X}_{1}\right)$

Dalam penelitian ini reward diukur dengan indikator intrinsic reward dan ekstrinsicreward dari Edirisooriya (2014) sebagai berikut :

Intrinsic reward:

a. Pengakuan, merupakan sebuah respon yang didapat berdasarkan penilaian dari kinerja yang dilakukan secara adil / fair

b. Tanggung jawab, tanggung jawab yang sesuai dengan kemampuan merupakan sesuatu yang diinginkan karyawan

c. Kesempatan belajar, dengan adanya kesempatan belajar akan menambah pengetahuan dan skill dari individu tersebut.

Ekstrinsic reward:

a. Gaji, gaji adalah balas jasa dalam bentuk uang yang diterima karyawan sebagai konsekuensi dari kedudukanya sebagai seorang karyawan yang memberikan sumbangan tenaga dan pikiran dalam mencapai tujuan perusahaan atau dapat dikatakan sebagai bayaran tetap yang diterima seseorang dari sebuah perusahaan 


\section{National Conference of Creative Industry: Sustainable Tourism Industry for Economic Development}

Universitas BundaMulia, Jakarta, 5-6 September 2018 e-ISSN No: 2622 - 7436

b. Bonus, Bonus adalah tambahan imbalan di atas atau di luar gaji/upah yang diberikan organisasi

c. Tunjangan, Tunjangan karyawan seperti dana pensiun, perawatan di rumah sakit dan liburan. Pada umumnya merupakan hal yang tidak berhubungan dengan kinerja karyawan, akan tetapi didasarkan pada senioritas atau catatan kehadiran

d. Promosi, manajer menjadikan penghargaan promosi sebagai usaha untuk menempatkan orang yang tepat pada pekerjaan yang tepat. Kinerja jika diukur dengan akurat, sering kali memberikan pertimbangan yang signifikan dalam alokasi penghargaan promosi.

2. Punishment $\left(\mathrm{X}_{2}\right)$

Indikator yang digunakan untuk mengukur punishment menurut Purwanto (2006) dalam penelitian Sunarto, et al. (2017) adalah punishment preventif dan punishment represif.

Variabel endogen dalam penelitian ini yaitu kinerja karyawan (Y). Menurut Chester I. Barnard dan Robert E. Quinn dalam Suyadi Prawirosentono (2008) Indikator kinerja karyawan adalah sebagai berikut :

1. Efektivitas dan Efisiensi

Efektivitas dari suatu organisasi apabila tujuan suatu organisasi dapat dicapai sesuai dengan kebutuhan yang direncanakan, efisiensi berkaitan dengan jumlah pengorbanan yang dikeluarkan dalam mencapai tujuan.

2. Otoritas dan tanggung jawab

Dalam hal ini otoritas adalah wewenang yang dimiliki seseorang untuk memerintah orang lain (bawahannya) untuk melaksanakan tugas yang dibebankan kepada masing-masing bawahan dalam suatu organisasi. Sedangkan tanggung jawab adalah bagian yang tidak terpisahkan atau sebagai akibat dari kepemilikan wewenang tersebut. Bila ada wewenang berarti dengan sendirinya muncul tanggung jawab.

3. Disiplin

Disiplin apabila taat pada hukum dan peraturan yang berlaku. Disiplin karyawan sebagai ketaatan karyawan bersangkutan dalam menghormati perjanjian kerja dimana karyawan bekerja.

4. Inisiatif

Inisiatif seseorang berkaitan dengan daya pikir, kreativitas dalam bentuk ide untuk suatu yang berkaitan dengan tujuan organisasi. Setiap inisiatif sebaliknya mendapat perhatian atau tanggapan positif dari atasan.

Variabel mediasi (intervening variable) dalam penelitian ini yaitu motivasi (M). indikator motivasi kerja menurut menurut Maslow dalam Mangkunegara (2013), adalah sebagai berikut :

1. Kebutuhan Fisiologis (Physiological Needs)

Kebutuhan Fisiologis (Physiological Needs) yaitu kebutuhan untuk mempertahankan hidup. Yang termasuk ke dalam kebutuhan ini adalah kebutuhan makan, minum, perumahan, dan sebagainya. Keinginan untuk memenuhi kebutuhan ini merangsang seseorang berperilaku atau bekerja giat. 


\section{National Conference of Creative Industry: \\ Sustainable Tourism Industry for Economic Development}

Universitas BundaMulia, Jakarta, 5-6 September 2018

e-ISSN No: 2622 - 7436

2. Kebutuhan Rasa Aman (Safety and Security Needs)

Kebutuhan Rasa Aman (Safety and Security Needs) adalah kebutuhan akan kebebasan dari ancaman yakni merasa aman dari ancaman kecelakaan dan keselamatan dalam melaksanakan pekerjaan.

3. Kebutuhan Sosial (Affiliation or Acceptance Needs)

Kebutuhan Sosial (Affiliation or Acceptance Needs) adalah kebutuhan sosial, teman, afiliasi, interaksi, dicintai dan mencintai, serta diterima dalam pergaulan kelompok pekerja dan masyarakat lingkungannya.

4. Kebutuhan Penghargaan Diri (Esteem or Status Needs)

Kebutuhan Penghargaan Diri (Esteem or Status Needs) adalah kebutuhan akan penghargaan diri dan pengakuan serta penghargaan prestise dari karyawan dan masyarakat lingkungannya. Prestise dan status dimanifestasikan oleh banyak hal yang digunakan sebagai simbol status itu.

5. Kebutuhan Aktualisasi Diri (Self Actualization)

Kebutuhan Aktualisasi Diri (Self Actualization) adalah kebutuhan akan aktualisasi diri dengan menggunakan kemampuan, keterampilan, dan potensi optimal untuk mencapai prestasi kerja yang sangat memuaskan.

\section{METODE ANALISIS}

Dengan melihat kerangka teoritis, maka teknik analisis data yang digunakan dalam penelitian ini adalah kuantitatif dengan menggunakan model SEM (Structural Equation Modeling) atau model persamaan struktural. Menurut Sugiyono (2016) SEM dapat dideskripsikan sebagai suatu analisis yang menggabungkan pendekatan analisis faktor (factor analysis), model struktural (structural model), dan analisis jalur (path analysis). Dengan demikian, di dalam analisis pemodelan persamaan structural (SEM) dapat dilakukan tiga macam kegiatan secara serentak, yaitu pengecekan validitas dan reliabilitas instrumen (berkaitan dengan analisis faktor konfirmatori), pengujian model hubungan antar variabel (berkaitan dengan analisis jalur), dan kegiatan untuk mendapatkan suatu model yang cocok untuk prediksi (berkaitan dengan anlisis regresi atau analisis model struktural). Menurut Ghozali (2014) tidak seperti analisis multivariate biasa (regresi berganda, analisis faktor), SEM dapat menguji secara bersama-sama :

(1) Model measurement : hubungan (nilai loading) antar indikator dengan konstruk (variabel laten).

(2) Model struktural : hubungan antara konstruk independen dengan dependen.

Software yang dipakai untuk analisis SEM dalam penelitian ini yaitu WarpPLS 3.0. SEMPLS dapat bekerja secara efisien dengan ukuran sampel yang kecil dan model yang kompleks.

\section{TAHAPAN PENGOLAHAN DATA}

Tahapan pengolahan data dalam penelitian ini dimulai dari penyebaran pilot test terlebih dahulu untuk memastikan bahwa indikator variabel dalam item-item pertanyaan kuesioner telah valid dan reliabel. Setelah indikator dalam setiap pertanyaan dinyatakan valid dan reliabel, peneliti menyebarkan kuesioner final pada karyawan tetap BCA. Pengisian pilot test dan kuesioner final tersebut diukur dengan menggunakan skala likert dan diberikan skor atau penilaian. Menurut Sugiyono (2012) skala likert digunakan untuk mengukur sikap, pendapat, dan persepsi seseorang atau sekelompok orang tentang 


\section{National Conference of Creative Industry: \\ Sustainable Tourism Industry for Economic Development}

Universitas BundaMulia, Jakarta, 5-6 September 2018

e-ISSN No: 2622 - 7436

fenomena sosial. Setelah itu hasil kuesioner yang telah diisi oleh responden ditabulasi ke dalam Microsoft Excel. Untuk mengolah data penelitian, peneliti menganalisis data menggunakan Structural Equation Modeling (SEM) dan dengan pengolahan data menggunakan software WarpPLS 3.0 untuk menguji hipotesis dan kualitas data.

\section{METODE PENGUJIAN VALIDITAS DAN RELIABILITAS}

Menurut Azwar (2016) validitas merupakan sejauh mana ketepatan atau kecermatan suatu instrumen pengukur dalam melakukan fungsi ukurnya. Pengertian validitas tersebut menunjukan ketepatan dan kesesuaian alat ukur yang digunakan untuk mengukur variabel. Pengukuran yang mempunyai validitas tinggi akan menghasilkan data yang akurat. Alat ukur dapat dikatakan valid jika benar-benar sesuai dan menjawab secara cermat tentang variabel yang akan diukur. Valid atau tidaknya data dapat dilihat berdasarkan kemampuan alat ukur tersebut dalam mencapai tujuan pengukuran yang dikehendaki. Dalam penelitian ini, pengujian validitas menggunakan program WarpPLS 3.0 pada model pengukuran (outer model) dimana tingkat validitas akan dilihat dari nilai validitas convergent, validitas discriminant, average variance ecxtracted (AVE).

Menurut Nazir (2014)reliable menyangkut ketepatan alat ukur yang digunakan untuk meneliti. Istilah reliabilitas dipakai untuk menunjukkan sejauh mana suatu hasil atau pengukuran dapat dipercaya dan diandalkan serta memberi hasil pengukuran yang relatif konsisten apabila pengukuran diulangi dua kali atau lebih. Menurut Sugiyono (2016) instrumen yang reliabel adalah instrumen yang bila digunakan beberapa kali untuk mengukur obyek yang sama, akan menghasilkan data yang sama. Dalam penelitian ini, pengujian reliabilitas menggunakan program WarpPLS 3.0 pada model pengukuran (outer model) dimana tingkat reliabilitas akan dilihat dari nilai koefisien alfa atau cronbanch's alpha dan composite reliability.

\section{METODE STATISTIKA}

Menurut Sugiyono (2016)Structural Equation Model (SEM) dapat dideskripsikan sebagai suatu analisis yang menggabungkan pendekatan analisis faktor (factor analysis), model struktural (structural model), dan analisis jalur (path analysis). SEM adalah teknik analisis statistika multivarian yang digunakan untuk menguji hubungan yang rumit antar beberapa variabel. Analisis multivarian adalah analisis statistika yang melibatkan lebih dari dua variabel dalam penelitian. Menurut Dachlan (2014) SEM sering digunakan karena bisa melakukan analisis secara sistematis dan menyeluruh terhadap sebuah model penelitian.

Para ahli metode penelitian mengelompokkan SEM menjadi dua pendekatan. Pendekatan pertama disebut sebagai Covariance Based SEM (CBSEM) dan Variance Based SEM atau yang lebih dikenal dengan Partial Least Squares (PLS). Hal utama yang membedakan antara PLS dan CBSEM adalah tujuan dari penggunaan metode. Tujuan dari penggunaan dari PLS adalah melakukan prediksi. Prediksi yang dimaksud disini adalah prediksi hubungan antar konstruk. Berbeda dengan PLS yang bertujuan untuk melakukan prediksi, penggunaan CBSEM lebih ditujukan sebagai metode untuk melakukan konfirmasi teori. Oleh karena itu, dalam penelitian ini peneliti menggunakan PLS karena akan memprediksi hubungan antar konstruk.

Menurut Jogiyanto dan Abdillah (2009) PLS (Partial Least Square) adalah analisis persamaan structural equation modeling (SEM) berbasis varian yang secara simultan 


\section{National Conference of Creative Industry: \\ Sustainable Tourism Industry for Economic Development}

Universitas BundaMulia, Jakarta, 5-6 September 2018

e-ISSN No: 2622 - 7436

dapat melakukan pengujian model pengukuran sekaligus pengujian model struktural. Selain itu menurut Haryono (2017)Partial Least Square (PLS) adalah salah satu metode alternatif dari Structural Equation Modeling (SEM) yang dapat digunakan untuk mengatasi permasalahan yang ada. PLS didesain untuk menyelesaikan regresi berganda ketika terjadi permasalahan spesifik pada data. PLS merupakan metode analisis yang powerfull karena tidak didasarkan pada banyak asumsi menurut Ghozali (2008).

Menurut Ghozali (2015) teknik analisis data menggunakan PLS-SEM dilakukan dua langkah evaluasi model yaitu:

1.) Model pengukuran (outer model) untuk mengetahui validitas dan reliabilitas indikator-indikator. Model Pengukuranatau outer model adalah hubungan antara variabel laten dan indikatornya, sering disebut uji indikator atau uji reliabilitas. Menurut Ghozali dan Latan (2015) model pengukuran atau outer model menunjukkan bagaimana variabel manifest atau inikator merepresentasikan variabel laten untuk diukur. Model ini digunakan untuk mengetahui validitas dan reabilitas yang menghubungkan indikator dengan variabel latennya. Namun sebelum melakukan evaluasi pada outer model, harus ditentukan terlebih dahulu apakah indikator pada variabel termasuk indikator reflektif atau formatif. PLS dapat sekaligus menganalisis konstruk yang dibentuk dengan indikator reflektif dan formatif.

Jika indikator dari variabel termasuk indikator reflektif, maka model pengukuran (outer model) ini dievaluasi dengan :

1. Uji Validitas

a.) Convergent Validity

Evaluasi awal atau pengujian pengukuran model bersifat reflektif yaitu dengan convergent validity. Evaluasi convergent validity dimulai dengan melihat item reliability (indikator validitas) yang ditunjukan oleh nilai loading factor. Menurut Shilihin dan Ratmono (2013) jika nilai loading factor lebih besar dari 0,70 maka dikatakan valid. Uji signifikansi dilihat dari p-value pada loading factor, jika pvalue $<0,05$ maka memiliki validitas yang signifikan.

b.) Discriminant Validity

Discriminant validity dilakukan dengan dua uji yaitu pertama menguji apakah indikator pada suatu konstruk akan mempunyai loading factor terbesar pada konstruk yang dibentuknya dengan melihat crossloading, jika korelasi konstruk dengan setiap indikatornya lebih besar dari pada ukuran konstruk lainnya, maka konstruk laten memprediksi indikatornya lebih baik dari pada konstruk lainnya. Uji yang kedua yaitu menguji Average Variance Extracted (AVE) untuk memastikan bahwa setiap konstruk memberikan variance yang lebih besar dengan ukurannya dari pada konstruk laten lainnya dalam model penelitian.Validitas dikatakan memiliki nilai yang baik berdasarkan rule of thumb jika nilai akar dari AVE untuk konstruk individual lebih besar dari nilai korelasi antar konstruk dengan konstruk lain dalam model dan harus lebih besar dari pada nilai yang direkomendasikan yaitu 0,50 dalam Sholihin dan Ratmono (2013).

2. Uji Reliabilitas

Uji Reliabilitas dilakukan pada outer model :

a. Composite Reliability. Data yang memiliki composite reliability> 0.7 mempunyai reliabilitas yang tinggi jika compesite reliability lebih besar dari 0,6 dikatakan cukup reliabel. 


\section{National Conference of Creative Industry: \\ Sustainable Tourism Industry for Economic Development}

Universitas BundaMulia, Jakarta, 5-6 September 2018

e-ISSN No: 2622 - 7436

b. Cronbach's Alpha. Dalam PLS, uji realibilitas diperkuat dengan adanya Cronbach's Alpha dimana kosistensi dari setiap jawaban yang diujikan. Cronbach's Alpha dikatakan baik apabila $\alpha \geq 0,7$ dan dikatakan cukup apabila $\alpha$ $\geq 0,6$.

Jika indikator dari variabel termasuk indikator formatif, maka model pengukuran (outer model) ini dievaluasi dengan:

1. Bobot indikator (indicator weight) harus signifikan secara statistis.

2. Multikolinearitas: Variance Inflation Factor (VIF) lebih kecil dari 3,3.

Namun Hair, et al.(2013) menyatakan bahwa tidak ada batasan yang jelas dalam membuat keputusan untuk mengukur secara reflektif atau formatif. Masalah ini bahkan telah menjadi topik debat dari berbagai disiplin ilmu yang belum sepenuhnya terpecahkan. Dalam penelitian ini, peneliti memutuskan bahwa indikator dalam setiap variabel merupakan indikator reflektif, karena setiap indikator dalam variabel penelitian merupakan perwujudan atau refleksi dari konstruknya menurut Sholihin dan Ratmono (2013).

2.) Model struktural (inner model) untuk mengetahui ketepatan model langkah terakhir dilakukan pengujian hipotesis.Dalam Sholihin dan Ratmono (2013) Structural model atau inner model atau disebut juga model struktural merupakan bagian pengujian hipotesis yang digunakan untuk menguji signifikansi variabel laten eksogen (independen) terhadap variabel laten endogen (dependen) dan nilai dari $\mathrm{R}^{2}$. Yang perlu dilakukan adalah :

1. Nilai Koefisien Determinasi ( $R$-squared)

Menguji nilai $R$-squared dimana0.75, 0.50, dan 0.25 menunjukan model substansial, moderate dan lemah. Nilai $R$-squared ini menunjukan berapa persentase variansi konstruk endogen dapat dijelaskan oleh konstruk yang dihipotesiskan memengaruhinya (endogen). Semakin tinggi $R$-squared menunjukkan model yang baik menurut Sholihin dan Ratmono (2013).

2. Relevansi Prediktif ( $Q$-squared)

Relevansi prediktif dilihat dari nilai $Q$-squared, dimana jika $Q$-squared $>0$, maka model memiliki predictive relevance sedangkan sebaliknya jika $<0$, maka model tidak memiliki predictive relevance. $Q$-squared mengukur seberapa baik nilai observasi yang dihasilkan oleh model dan juga estimasi parameternya. Jika nilai $Q$ squared semakin mendekati angka 1 berarti model semakin baik.

3. Ukuran Efek (F-squared Effect Size)

Effect size dihitung sebagai nilai absolut kontribusi individual setiap variabel laten prediktor pada nilai $R$-squared variabel kriterion. Effect size dikelompokkan menjadi tiga kategori yaitu lemah $(0,02)$, medium $(0,15)$, dan besar $(0,35)$ seperti dalam Hair, et al.(2013).

\section{HASIL PENELITIAN DAN PEMBAHASAN}

\section{Pengujian Model Pengukuran (Outer Model)}

1.) Convergent Validity (Validitas Konvergen)

Menurut Sholihin dan Ratmono (2013) evaluasi convergent validity dimulai dengan melihat item reliability (indikator validitas) yang ditunjukan oleh nilai loading factor. Jika nilai loading factor lebih besar dari 0,70 maka dikatakan valid. 
Uji signifikansi dilihat dari p-value pada loading factor, jika p-value $<0,05$ maka memiliki validitas yang signifikan. Hasil olah data menggunakan warpPLS 3.0 adalah sebagai berikut :

\section{Tabel 1 -Combined Loadings and Cross-Loadings}

\begin{tabular}{|c|c|c|c|c|c|c|}
\hline & Reward & Punishment & Motivasi & Kinerja & $\mathrm{SE}$ & P Value \\
\hline $\mathrm{R} 1$ & $(0.718)$ & 0.532 & -0.223 & -0.356 & 0.093 & $<0.001$ \\
\hline $\mathrm{R} 2$ & $(0.557)$ & 0.206 & -0.546 & 0.116 & 0.138 & $<0.001$ \\
\hline R3 & $(0.717)$ & 0.415 & 0.158 & 0.172 & 0.103 & $<0.001$ \\
\hline $\mathrm{R} 4$ & $(0.825)$ & 0.665 & -0.075 & 0.029 & 0.098 & $<0.001$ \\
\hline R5 & $(0.876)$ & -0.053 & -0.167 & -0.012 & 0.077 & $<0.001$ \\
\hline R6 & $(0.867)$ & -0.506 & 0.127 & 0.078 & 0.105 & $<0.001$ \\
\hline R7 & $(0.724)$ & -0.496 & 0.499 & -0.113 & 0.092 & $<0.001$ \\
\hline $\mathrm{R} 8$ & $(0.854)$ & -0.344 & 0.349 & -0.121 & 0.059 & $<0.001$ \\
\hline R9 & $(0.797)$ & -0.067 & -0.048 & 0.049 & 0.107 & $<0.001$ \\
\hline R10 & $(0.703)$ & -0.217 & -0.244 & 0.187 & 0.091 & $<0.001$ \\
\hline P1 & 0.116 & $(0.905)$ & -0.219 & -0.203 & 0.051 & $<0.001$ \\
\hline $\mathrm{P} 2$ & 0.080 & $(0.922)$ & -0.252 & -0.082 & 0.060 & $<0.001$ \\
\hline P3 & -0.043 & $(0.965)$ & 0.003 & 0.025 & 0.056 & $<0.001$ \\
\hline $\mathrm{P} 4$ & -0.136 & $(0.916)$ & 0.226 & -0.015 & 0.067 & $<0.001$ \\
\hline P5 & 0.117 & $(0.893)$ & 0.166 & -0.023 & 0.080 & $<0.001$ \\
\hline P6 & -0.140 & $(0.831)$ & 0.088 & 0.325 & 0.095 & $<0.001$ \\
\hline M1 & -0.050 & 0.356 & $(0.799)$ & 0.041 & 0.114 & $<0.001$ \\
\hline M2 & -0.138 & 0.283 & (0.888) & -0.232 & 0.066 & $<0.001$ \\
\hline M3 & -0.091 & -0.029 & $(0.954)$ & -0.228 & 0.026 & $<0.001$ \\
\hline M4 & 0.142 & 0.055 & $(0.877)$ & -0.157 & 0.054 & $<0.001$ \\
\hline M5 & -0.031 & -0.093 & (0.884) & 0.062 & 0.062 & $<0.001$ \\
\hline M6 & 0.214 & -0.258 & $(0.736)$ & 0.468 & 0.111 & $<0.001$ \\
\hline M7 & -0.007 & -0.341 & $(0.836)$ & 0.154 & 0.066 & $<0.001$ \\
\hline $\mathrm{K} 1$ & 0.100 & -0.025 & -0.165 & $(0.706)$ & 0.113 & $<0.001$ \\
\hline $\mathrm{K} 2$ & -0.370 & 0.330 & -0.020 & $(0.826)$ & 0.119 & $<0.001$ \\
\hline K3 & -0.088 & 0.027 & 0.229 & $(0.867)$ & 0.087 & $<0.001$ \\
\hline $\mathrm{K} 4$ & -0.297 & -0.303 & 0.396 & $(0.742)$ & 0.096 & $<0.001$ \\
\hline $\mathrm{K} 5$ & 0.353 & -0.352 & 0.089 & $(0.848)$ & 0.042 & $<0.001$ \\
\hline K6 & 0.197 & 0.275 & -0.505 & $(0.829)$ & 0.060 & $<0.001$ \\
\hline $\mathrm{K} 7$ & 0.086 & 0.022 & -0.021 & $(0.811)$ & 0.066 & $<0.001$ \\
\hline
\end{tabular}

Sumber : Hasil olah data peneliti dengan Warp PLS 3.0 (2018)

Dapat dilihat pada tabel 1 hasil dari Combined Loadings and Cross-Loadings, kolom pertama menjelaskan indikator setiap variabel yang telah diubah menjadi poin-poin pertanyaan pada kuesioner, sedangkan baris pertama menjelaskan variabel penelitian. Nilai loading factor indikator setiap variabel sudah memenuhi syarat suatu indikator dikatakan valid, kecuali indikator R2 (pertanyaan nomor 2 bagian reward di kuesioner) pada variabel reward menunjukan nilai sebesar 0.557 yang berarti tidak valid. Oleh karena itu, peneliti memutuskan untuk menghilangkan pertanyaan nomor 2 dari pilot test kuesioner.

2.) Validitas Diskriminan

Untuk pengujian validitas diskriminan, pertama dengan melihat nilai akar kuadrat Average Variance Extracted (AVE). Kriteria yang digunakan adalah akar kuadrat AVE harus lebih tinggi dari korelasi antar variabel laten pada kolom yang sama. Jika tidak terpenuhi maka validitas diskriminan rendah atau dengan kata lain ada indikator yang mempunyai loading kuat pada lebih dari satu variabel laten. Jika 
hal ini terjadi maka kita harus memeriksa tabel loading dan cross-loadings kembali untuk memastikan indikator yang redudant tersebut serta mempertimbangkan untuk menghapusnya menurut Sholihin dan Ratmono (2013). Berikut adalah hasil uji validitas diskriminan :

Tabel 2 - Latent Variable Correlations

\begin{tabular}{lcccc}
\hline & Reward & Punishment & Motivasi & Kinerja \\
Reward & $(0.792)$ & 0.749 & 0.784 & 0.700 \\
Punishment & 0.749 & $(0.906)$ & 0.766 & 0.830 \\
Motivasi & 0.784 & 0.766 & $(0.856)$ & 0.753 \\
Kinerja & 0.700 & 0.830 & 0.753 & $(0.806)$ \\
\hline
\end{tabular}

Sumber : Hasil olah data peneliti dengan Warp PLS 3.0 (2018)

Nilai AVE pada masing-masing variabel ditunjukkan dengan angka yang terdapat dalam tanda kurung. Nilai yang ada di dalam tanda kurung harus lebih tinggi dari nilai lain pada kolom yang sama. Jika dilihat hasilnya pada tabel 2, nilai AVE pada reward, punishment, motivasi telah memenuhi kriteria validitas diskriminan, tetapi nilai AVE pada kinerja tidak memenuhi kriteria, karena ada nilai AVE pada punishment yang lebih tinggi jika dibandingkan kinerja. Oleh karena itu, peneliti kembali memeriksa tabel loading dan cross-loadings kemudianmemutuskan untuk menghapus indikator K1 karena pada tabel 1, nilai loading pada indikator K1 menunjukkan angka yang mendekati 0.70 (syarat minimal nilai loading dikatakan valid) Sholihin dan Ratmono (2013). Setelah menghapus indikator K1, diperoleh hasil sebagai berikut :

Tabel 3 - Latent Variable Correlations

\begin{tabular}{lcccc}
\hline & Reward & Punishment & Motivasi & Kinerja \\
Reward & $(0.792)$ & 0.749 & 0.784 & 0.701 \\
Punishment & 0.749 & $(0.906)$ & 0.766 & 0.825 \\
Motivasi & 0.784 & 0.766 & $(0.856)$ & 0.751 \\
Kinerja & 0.701 & 0.825 & 0.751 & $(0.828)$ \\
\hline
\end{tabular}

Sumber : Hasil olah data peneliti dengan WarpPLS 3.0 (2018)

Setelah indikator K1 dihapus, nilai AVE pada kinerja memenuhi kriteria validitas diskriminan.

3.) Reliabilitas Konsistensi Internal

Untuk menguji reliabilitas pada WarpPLS 3.0, dapat dilihat pada nilai composite reliability dan cronbach alpha. Nilai composite reliability dan cronbach alpha yang lebih besar dari 0.70 mempunyai reliabilitas yang tinggi jika composite reliability lebih besar dari 0,6 dikatakan cukup reliabel berdasarkan Sholihin dan Ratmono (2013).

Tabel 4 - Latent Variable Coefficients

\begin{tabular}{lcccc}
\hline & Reward & Punishment & Motivasi & Kinerja \\
R-squared & & & 0.686 & 0.758 \\
Composite Reliability & 0.938 & 0.965 & 0.950 & 0.929 \\
Cronbach's Alpha & 0.924 & 0.956 & 0.938 & 0.908 \\
Avg. Var. Extrac. & 0.628 & 0.821 & 0.733 & 0.685 \\
Full Collin. VIF & 3.028 & 4.000 & 3.428 & 3.524 \\
$Q$-squared & & & 0.689 & 0.730 \\
\hline
\end{tabular}

Sumber : Hasil olah data peneliti dengan WarpPLS 3.0 (2018) 
Pada tabel 4 nilai composite reliability dan cronbach alpha telah memenuhi kriteria yaitu $>0.70$, yang berarti instrumen pada variabel dapat dikatakan reliabel.

\section{Pengujian Model Struktural (Inner Model)}

Inner model atau model struktural pada prinsipnya adalah menguji pengaruh antara satu variabel laten dengan variabel laten lainnya. Dapat dikatakan juga menguji hipotesis antara variabel laten yang satu dengan yang lain. Pengujian dilakukan dengan melihat persentase varian yang dijelaskan yaitu $R$-squared untuk variabel laten dependen yang dimodelkan mendapatkan pengaruh dari variabel laten independen, serta melihat koefisien jalur strukturalnya. Pengujian model struktural dilakukan dengan cara sebagai berikut :

1.) Nilai Koefisien Determinan (R-squared)

Nilai koefisien determinan $\left(\mathrm{R}^{2}\right)$ digunakan untuk mengukur tingkat variasi perubahan variabel independen terhadap variabel dependen. Semakin tinggi nilai $\mathrm{R}^{2}$ berarti semakin baik model prediksi dari model penelitian yang diajukan. Berdasarkan hasil dari output WarpPLS 3.0 diketahui bahwa nilai $R$-squared $\left(\mathrm{R}^{2}\right)$ dari variabel-variabel sebagai berikut :

Tabel 5 - R-squared

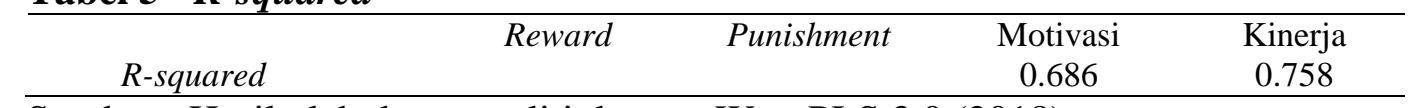

Sumber : Hasil olah data peneliti dengan WarpPLS 3.0 (2018)

Tabel 5 menunjukan bahwa nilai $R$-squaredvariabel motivasi (M) adalah sebesar 0.686 yang berarti variabel motivasi dipengaruhi oleh proporsi reward dan punishment sebesar $68,6 \%$ sedangkan sisanya sebesar $31,4 \%$ dijelaskan oleh konstruk lain diluar model penelitian. Selanjutnya untuk nilai $R$-squaredvariabel kinerja karyawan $(\mathrm{Y})$ menunjukan nilai sebesar 0.758 yang berarti variabel kinerja karyawan dipengaruhi oleh proporsi reward, punishment, dan motivasi sebesar $75,8 \%$ sedangkan sisanya sebesar $24,2 \%$ dijelaskan oleh konstruk lain diluar model penelitian. Menurut Sholihin dan Ratmono (2013) jika nilai $R$-squared $>0.50$ berarti variabel laten endogen dalam model struktural dapat diinterpretasikan sebagai substansial.

2.) Relevansi Prediktif ( $Q$-Squared)

Menurut Sholihin dan Ratmono (2013) nilai $Q$-squared jika lebih besar dari nol mengindikasikan bahwa variabel laten eksogen mempunyai relevansi prediktif pada variabel laten endogen yang dipengaruhi.

Tabel 6 - Q-Squared

\begin{tabular}{|c|c|c|c|}
\hline$Q$-squared & Reward & Punishment & $\begin{array}{c}\text { Motivasi } \\
0.689\end{array}$ \\
\hline
\end{tabular}

Sumber : Hasil olah data peneliti dengan WarpPLS 3.0 (2018)

Pada tabel 6 menunjukkan bahwa nilai $Q$-squared telah memenuhi kriteria, yang berarti memiliki validitas prediktif yang baik. 


\section{3.) Ukuran Efek (F-Squared)}

Nilai efek dihitung sebagai nilai absolut kontribusi individual setiap variabel laten prediktor pada nilai $R$-squared variabel kriterion. Ukuran efek ini dapat dikelompokkan menjadi 3 kategori yaitu lemah $(0,02)$, medium $(0,15)$, dan besar $(0,35)$.

Tabel 7 - Standard Errors and Effect Size for Path Coefficient

\begin{tabular}{lcccc}
\hline & Reward & Punishment & Motivasi & Kinerja \\
$\begin{array}{l}\text { Reward } \\
\text { Motivhment }\end{array}$ & & & & \\
Motivasi & 0.364 & 0.322 & & \\
Kinerja & 0.016 & 0.418 & 0.356 & \\
\hline
\end{tabular}

Sumber : Hasil olah data peneliti dengan WarpPLS 3.0 (2018)

Hasil pada tabel 7 menunjukkan bahwa nilai efek pengaruh reward terhadap motivasi sebesar 0.364 yang berarti reward memiliki peran yang penting karena dapat meningkatkan motivasi karyawan. Nilai efek pengaruh punishment terhadap motivasi juga memiliki peran penting dalam meningkatkan motivasi karyawan dengan nilai 0.322. Sedangkan nilai efek pengaruh reward terhadap kinerja menunjukkan nilai sebesar 0.016 yang berarti tidak memiliki peran penting terhadap kinerja. Sementara nilai pengaruh punishment dan motivasi terhadap kinerja cukup besar yaitu sebesar 0.418 dan 0.356 berarti memiliki peran penting terhadap kinerja.

\section{Pengujian Hipotesis}

Hubungan antar konstruk laten dalam model penelitian dapat dilihat dari hasil esimasi koefisien jalur (path coefficients) dan tingkat signifikansinya (p-value). Tingkat signifikansinya yang dipakai dalam penelitian ini adalah 5\%. Pengujian efek mediasi dilihat dengan membagi dua pengujian model yaitu model langsung (direct effect) dan model tidak langsung (indirect effect). Berikut ini output dari pengujian model langsung (direct effect) dengan menggunakan WarpPLS 3.0 yang ditampilkan pada gambar 2, dapat dilihat pada gambar berikut :

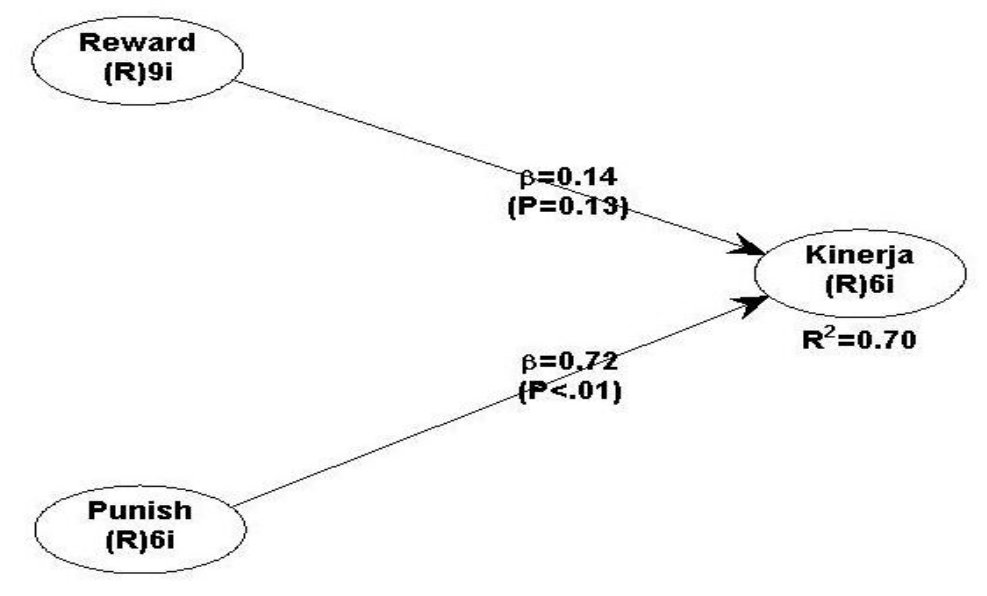

Gambar 2. Hasil Output Model Direct Effect

Sumber : Hasil oleh data peneliti dengan WarpPLS 3.0 (2018) 
Selanjutnya mengestimasi model indirect effect (pengaruh tidak langsung) dengan memasukan variabel mediasi, kemudian menghubungkan secara simultan antara variabel prediktor terhadap variabel mediasi, variabel mediasi terhadap variabel kriterion dan variabel prediktor terhadap variabel kriterion. Berikut tampilan gambar model indirect effect beserta dengan hasil pengujian menggunakan WarpPLS 3.0 :

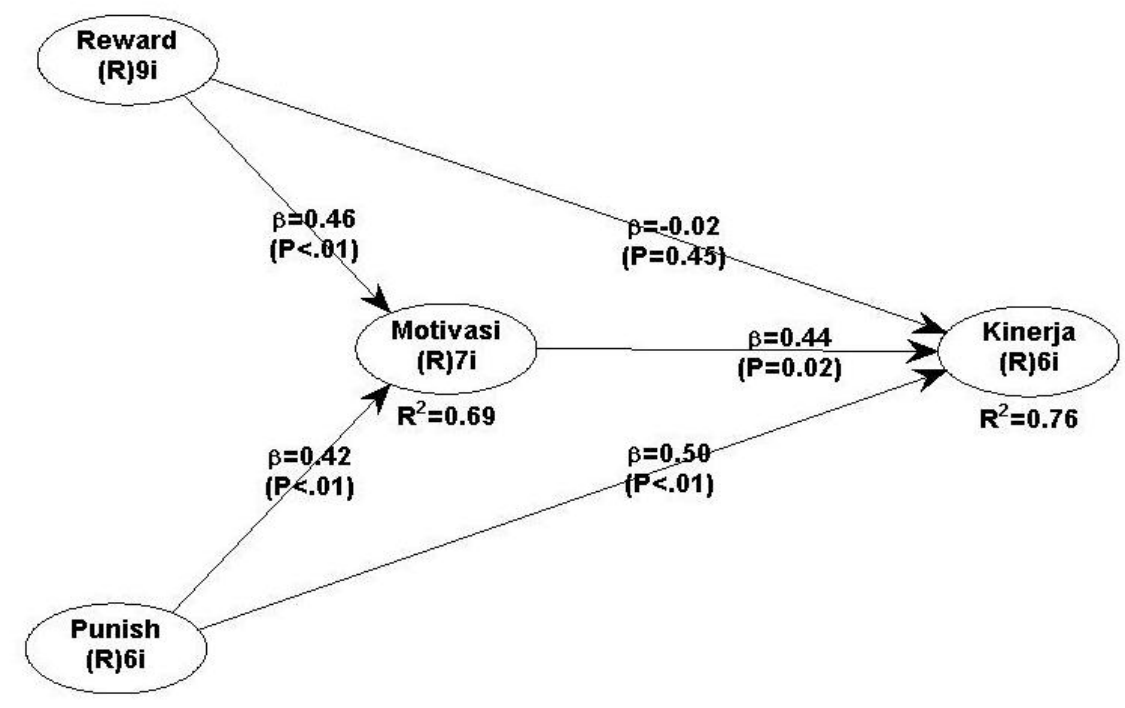

\section{Gambar 3. Hasil Output Model Indirect Effect}

Sumber : Hasil olah data penulis dengan WarpPLS 3.0 (2018)

Berdasarkan hasil pengolahan data diatas yang menggunakan WarpPLS 3.0 maka, berikut ini merupakan pengujian hipotesis yang akan diuraikan secara berurutan berdasarkan model pengujian pengaruh langsung (direct efect) dan model pengujian pengaruh tidak langsung (indirect effect) :

\section{Reward $\left(\mathrm{X}_{1}\right)$ terhadap Kinerja Keuangan (Y)}

a. Hipotesis

$\mathrm{H}_{1}$ : Reward berpengaruh positif dan signifikan terhadap kinerja karyawan.

$\mathrm{H}_{0}$ : Reward tidak berpengaruh positif dan signifikan terhadap kinerja karyawan.

b. Menerima atau menolak hipotesis

Dasar pengambilan keputusan bahwa jika $p$-value $>0.05$ maka $\mathrm{H}_{0}$ diterima sementara $\mathrm{H}_{1}$ ditolak, sedangkan jika $p$-value $<0.05$ maka $\mathrm{H}_{0}$ ditolak dan $\mathrm{H}_{1}$ diterima. Nilai $p$-value pada reward terhadap kinerja karyawan adalah 0.13 (> 0.05), maka $\mathrm{H}_{0}$ diterima dan $\mathrm{H}_{1}$ ditolak dengan nilai koefisien jalur sebesar 0.14. Berarti proporsi reward tidak memiliki pengaruh signifikan terhadap kinerja karyawan. Artinya semakin meningkat proporsi reward dampaknya tidak signifikan terhadap kinerja karyawan atau besar kecilnya reward yang diterima para karyawan tidak berpengaruh besar terhadap kinerja karyawan. Hal ini sejalan dengan penelitian oleh Suak, et al.(2017) yang menyatakan bahwa reward tidak memiliki pengaruh yang signifikan terhadap kinerja karyawan. 


\section{Reward $\left(\mathrm{X}_{1}\right)$ terhadap Motivasi (M)}

a. Hipotesis

$\mathrm{H}_{2}$ : Reward berpengaruh positif dan signifikan terhadap motivasi.

$\mathrm{H}_{0}$ : Reward tidak berpengaruh positif dan signifikan terhadap motivasi.

b. Menerima atau menolak hipotesis

Dasar pengambilan keputusan bahwa jika $p$-value $>0.05$ maka $\mathrm{H}_{0}$ diterima sementara $\mathrm{H}_{2}$ ditolak, sedangkan jika $p$-value $<0.05$ maka $\mathrm{H}_{0}$ ditolak dan $\mathrm{H}_{2}$ diterima. Nilai $p$-value pada reward terhadap motivasi adalah $<0.01(<0.05)$, maka $\mathrm{H}_{0}$ ditolak dan $\mathrm{H}_{2}$ diterima dengan nilai koefisien jalur sebesar 0.46 . Berarti proporsi reward terhadap motivasi memiliki pengaruh signifikan. Artinya semakin meningkat proporsi reward dampaknya signifikan terhadap motivasi. Hal ini sejalan dengan penelitian oleh Febrianti, et al.(2014) yang menyatakan bahwa reward berpengaruh signifikan terhadap motivasi.

\section{Punishment $\left(\mathrm{X}_{2}\right)$ terhadap Kinerja Karyawan (Y)}

a. Hipotesis

$\mathrm{H}_{3}$ : Punishment berpengaruh positif dan signifikan terhadap kinerja karyawan.

$\mathrm{H}_{0}$ :Punishment tidak berpengaruh positif dan signifikan terhadap kinerja karyawan.

b. Menerima atau menolak hipotesis

Dasar pengambilan keputusan bahwa jika $p$-value $>0.05$ maka $\mathrm{H}_{0}$ diterima sementara $\mathrm{H}_{3}$ ditolak, sedangkan jika $p$-value $<0.05$ maka $\mathrm{H}_{0}$ ditolak dan $\mathrm{H}_{3}$ diterima. Nilai p-value pada punishment terhadap kinerja karyawan adalah < 0.01 ( $<0.05$ ), maka $\mathrm{H}_{0}$ ditolak dan $\mathrm{H}_{3}$ diterima dengan nilai koefisien jalur sebesar 0.50. Berarti proporsi punishment memiliki pengaruh signifikan terhadap kinerja karyawan. Artinya semakin meningkat proporsi punishment dampaknya signifikan terhadap kinerja karyawan. Hal ini sejalan dengan penelitian oleh Sunarto, et al.(2017) yang menyatakan bahwa punishment berpengaruh signifikan terhadap kinerja karyawan.

\section{Punishment $\left(\mathrm{X}_{2}\right)$ terhadap Motivasi (M)}

a. Hipotesis

$\mathrm{H}_{4}$ : Punishment berpengaruh positif dan signifikan terhadap motivasi.

$\mathrm{H}_{0}$ : Punishment tidak berpengaruh positif dan signifikan terhadap motivasi.

b. Menerima atau menolak hipotesis

Dasar pengambilan keputusan bahwa jika $p$-value $>0.05$ maka $\mathrm{H}_{0}$ diterima sementara $\mathrm{H}_{4}$ ditolak, sedangkan jika $p$-value $<0.05$ maka $\mathrm{H}_{0}$ ditolak dan $\mathrm{H}_{4}$ diterima. Nilai p-value pada punishment terhadap motivasi adalah $<0.01(<$ 0.05), maka $\mathrm{H}_{0}$ ditolak dan $\mathrm{H}_{4}$ diterima dengan nilai koefisien jalur sebesar 0.42 . Berarti proporsi punishment memiliki pengaruh signifikan terhadap motivasi. Artinya semakin meningkat proporsi punishment dampaknya signifikan terhadap motivasi. Hal ini sejalan dengan penelitian oleh Purwantono (2014) yang menyatakan bahwa punishment memiliki pengaruh signifikan terhadap motivasi. 


\section{National Conference of Creative Industry: \\ Sustainable Tourism Industry for Economic Development}

Universitas BundaMulia, Jakarta, 5-6 September 2018

e-ISSN No: 2622 - 7436

\section{Motivasi (M) terhadap Kinerja Karyawan (Y)}

a. Hipotesis

$\mathrm{H}_{5}$ : Motivasi berpengaruh positif dan signifikan terhadap kinerja karyawan.

$\mathrm{H}_{0}$ : Motivasi tidak berpengaruh positif dan signifikan terhadap kinerja karyawan.

b. Menerima atau menolak hipotesis

Dasar pengambilan keputusan bahwa jika $p$-value $>0.05$ maka $\mathrm{H}_{0}$ diterima sementara $\mathrm{H}_{5}$ ditolak, sedangkan jika $p$-value $<0.05$ maka $\mathrm{H}_{0}$ ditolak dan $\mathrm{H}_{5}$ diterima. Nilai p-value pada motivasi terhadap kinerja karyawan adalah $0.02(<$ 0.05), maka $\mathrm{H}_{0}$ ditolak dan $\mathrm{H}_{5}$ diterima dengan nilai koefisien jalur sebesar 0.44. Berarti proporsi motivasi memiliki pengaruh signifikan terhadap kinerja karyawan. Artinya semakin meningkat proporsi motivasi dampaknya signifikan terhadap kinerja karyawan. Hal ini sejalan dengan penelitian oleh Prabu dan Wijayanti (2016) yang menyatakan bahwa motivasi berpengaruh signifikan terhadap kinerja karyawan.

\section{- Syarat Pengujian Hipotesis Mediasi}

Persyaratan efek mediasi yang harus dipenuhi menurut Sholihin dan Ratmono (2013) adalah :

i. $\quad$ Koefisien jalur c (model direct effect sebelum dimasukan variabel moderasi) harus signifikan.

ii. Koefisien jalur a (koefisien jalur dari variabel prediktor ke variabel mediasi) dan $b$ (koefisien jalur dari variabel mediasi ke variabel kriterion) harus signifikan setelah dimasukan variabel mediasi ke dalam model.

Pengambilan kesimpulan efek mediasi adalah :

a. Jika koefisien jalur c"(koefisien indirect effect variabel prediktor ke variabel kriterion) dari hasil estimasi tetap signifikan dan tidak berubah $(\mathrm{c} "=\mathrm{c})$ maka hipotesis mediasi tidak didukung.

b. Jika koefisien jalur c" (koefisien indirect effect variabel prediktor ke variabel kriterion) nilainya turun $(c "<c)$ tetapi tetap signifikan maka bentuk mediasi adalah mediasi sebagian (partial mediation).

c. Jika koefisien jalur c" (koefisien indirect effect variabel prediktor ke variabel kriterion) nilainya turun $(\mathrm{c} "<\mathrm{c})$ dan menjadi tidak signifikan maka bentuk mediasi adalah mediasi penuh (full mediation) Sholihin dan Ratmono (2013).

\section{Reward $\left(\mathrm{X}_{1}\right)$ terhadap Kinerja Karyawan (Y) yang dimediasi oleh Motivasi} (M)

a. Hipotesis

$\mathrm{H}_{6}$ : Reward berpengaruh positif dan signifikan terhadap kinerja karyawan dengan dimediasi oleh motivasi.

$\mathrm{H}_{0}$ : Reward tidak berpengaruh positif dan signifikan terhadap kinerja karyawan dengan dimediasi oleh motivasi.

b. Menerima atau menolak hipotesis

Karena hubungan langsung antara variabel prediktor reward tidak signifikan terhadap variabel kriterion kinerja keuangan sebelum dimediasi oleh 


\section{National Conference of Creative Industry: \\ Sustainable Tourism Industry for Economic Development}

Universitas BundaMulia, Jakarta, 5-6 September 2018

e-ISSN No: 2622 - 7436

motivasi yaitu dengan nilai p-value sebesar 0.45 (diatas nilai 0.05), maka penelitian untuk hipotesis ini tidak dapat dilanjutkan, karena tidak memenuhi syarat pengujian mediasi.

\section{Punishment $\left(\mathrm{X}_{2}\right)$ terhadap Kinerja Karyawan (Y) yang dimediasi oleh Motivasi (M)}

a. Hipotesis

$\mathrm{H}_{7}$ : Punishment berpengaruh positif dan signifikan terhadap Kinerja Karyawan dengan dimediasi oleh Motivasi

$\mathrm{H}_{0}$ : Punishment tidak berpengaruh positif dan signifikan terhadap Kinerja Karyawan dengan dimediasi oleh Motivasi

b. Menerima atau menolak hipotesis

Pengaruh punishment tehadap kinerja karyawan telah memenuhi kriteria (i) yaitu nilai koefisien jalur pada model direct effect harus signifikan dengan nilai $p$-value $<0.01$ (dibawah nilai 0.05) dan persayaratan kedua dimana koefisien jalur dari variabel prediktor (punishment) ke variabel mediasi (motivasi) signifikan dengan $p$-value adalah $<0.01$ (dibawah nilai 0.05) dan koefisien jalur dari variabel mediasi (motivasi) ke variabel kriterion (kinerja karyawan) signifikan dengan nilai $p$-value adalah $<0.01$ (dibawah nilai 0.05). Karena koefisien indirect effect variabel prediktor ke variabel kriterion turun dari nilai koefisien direct effect yaitu dari 0.72 menjadi 0.50 dan tetap signifikan ditunjukan dengan nilai $p$-value sebesar $<0.01$ maka bentuk mediasi adalah mediasi sebagian (partial mediation) sehingga keputusan akhirnya adalah $\mathrm{H}_{0}$ ditolak dan $\mathrm{H}_{7}$ diterima. Maka dapat disimpulkan bahwa terdapat pengaruh tidak langsung antara punishment terhadap kinerja karyawan. Artinya terdapat pengaruh proporsi punishment terhadap kinerja karyawan dengan dimediasi oleh motivasi.

\section{KESIMPULAN DAN IMPLIKASI}

\section{Kesimpulan}

Berdasarkan hasil penelitian dan pembahasan yang telah dilakukan mengenai pengaruh variabel reward dan punishment terhadap kinerja karyawan yang dimediasi oleh variabel motivasi pada karyawan tetap BCA, maka kesimpulan yang dapat diperoleh dari penelitian ini adalah :

1. Reward berpengaruh positif dan tidak signifikan signifikan terhadap kinerja karyawan BCA. Hasil pengujian yang dilakukan menggunakan WarpPLS 3.0 menunjukkan nilai signifikansi sebesar 0.14 (>0.05). Hal ini menunjukkan bahwa reward yang diterima karyawan baik itu reward intrinsik maupun reward ekstrinsik belum dapat mempengaruhi kinerja karyawan BCA secara signifikan. Hal ini sejalan dengan penelitian oleh Suak, et al.(2017) yang menyatakan bahwa reward tidak memiliki pengaruh yang signifikan terhadap kinerja karyawan.

2. Reward berpengaruh positif dan signifikan terhadap motivasi karyawan BCA. Hasil pengujian yang dilakukan menggunakan WarpPLS 3.0 menunjukkan nilai signifikansi sebesar $<0.01$ (< 0.05). Hal ini menunjukkan bahwa reward mempengaruhi motivasi karyawan BCA secara signifikan. Hal ini sejalan dengan 


\section{National Conference of Creative Industry: \\ Sustainable Tourism Industry for Economic Development}

Universitas BundaMulia, Jakarta, 5-6 September 2018

e-ISSN No: 2622 - 7436

penelitian oleh Febrianti, et al.(2014) yang menyatakan bahwa reward berpengaruh signifikan terhadap motivasi.

3. Punishment berpengaruh positif dan signifikan terhadap kinerja karyawan BCA. Hasil pengujian yang dilakukan menggunakan WarpPLS 3.0 menunjukkan nilai signifikansi sebesar $<0.01(<0.05)$. Hal ini menunjukkan bahwa punishment mempengaruhi kinerja karyawan BCA secara signifikan. Hal ini sejalan dengan penelitian oleh Sunarto, et al.(2017) yang menyatakan bahwa punishment berpengaruh signifikan terhadap kinerja karyawan.

4. Punishment berpengaruh positif dan signifikan terhadap motivasi karyawan BCA. Hasil pengujian yang dilakukan menggunakan WarpPLS 3.0 menunjukkan nilai signifikansi sebesar $<0.01(<0.05)$. Hal ini menunjukkan bahwa punishment mempengaruhi motivasi karyawan BCA secara signifikan. Hal ini sejalan dengan penelitian oleh Purwantono (2014) yang menyatakan bahwa punishment memiliki pengaruh signifikan terhadap motivasi.

5. Motivasi berpengaruh positif dan signifikan terhadap kinerja karyawan BCA. Hasil pengujian yang dilakukan menggunakan WarpPLS 3.0 menunjukkan nilai signifikansi sebesar 0.02 ( $<0.05)$. Hal ini menunjukkan bahwa motivasi mempengaruhi kinerja karyawan BCA secara signifikan. Hal ini sejalan dengan penelitian oleh Prabu dan Wijayanti (2016) yang menyatakan bahwa motivasi berpengaruh signifikan terhadap kinerja karyawan.

6. Motivasi tidak memediasi pengaruh reward terhadap kinerja karyawan. Kondisi ini disebabkan karena disaat tidak dimediasi oleh motivasi pun, reward tidak mempengaruhi kinerja karyawan secara langsung sehingga diasumsikan tidak terdapat pengaruh tidak langsung. Hal ini disebabkan karena terdapat faktor lain yang lebih dominan mempengaruhi kinerja keuangan dibandingkan reward.

7. Motivasi memediasi sebagian (partial mediation) pengaruh punishment terhadap kinerja karyawan. Kondisi ini disebabkan karena adanya kemungkinan terdapat variabel lain yang memediasi pengaruh punishment terhadap kinerja karyawan.

\section{Saran}

Setelah peneliti melakukan penelitian serta telah menarik kesimpulan, maka peneliti memberikan beberapa saran sebagai berikut:

1. Bagi BCA sebaiknya memberikan pemahaman yang lebih mendalam tentang reward dan punishment yang hendak diberikan serta bagaimana reward dan punishment tersebut dapat diterima sehingga dapat benar-benar berdampak positif bagi karyawan.

2. Bagi BCA sebaiknya lebih menyesuaikan kembali sistem reward yang diberikan pada karyawan agar sesuai dengan kontribusi yang mereka berikan.

3. Bagi karyawan BCA sebaiknya lebih meningkatkan kemampuan yang ada agar lebih mampu menghadapi tugas yang sulit dan menantang demi kemajuan bank.

4. Bagi penelitian selanjutnya diharapkan dapat menguji kembali variabelvariabel yang belum berhasil menunjukkan pengaruhnya secara signifikan terhadap kinerja karyawan, diharapkan dapat menambah variabel lainnya yang dapat mempengaruhi kinerja karyawan dan menambah sampel yang diteliti agar mendapatkan hasil analisis yang lebih baik lagi. 


\section{National Conference of Creative Industry: \\ Sustainable Tourism Industry for Economic Development}

Universitas BundaMulia, Jakarta, 5-6 September 2018

e-ISSN No: 2622 - 7436

\section{DAFTAR PUSTAKA}

Abdillah, W., \& Jogiyanto, H. M. (2009). Konsep Dan Aplikasi PLS (Partial Least Square) Untuk Penelitian Empiris. Yogyakarta: Badan Penerbit Fakultas Ekonomi Dan Bisnis UGM.

Aliyu, N. S., Jamil, C. M., \& Mohamed, R. (2014). The Mediating Role of Management Control System in the Relationship between Corporate Governance and the Performance of Bailed-out Banks in Nigeria. Procedia - Social and Behavioral Sciences - ISSN : 1877-0428, 613-620.

Anwar, \& Dunija, T. (2016). Pengaruh Sistem Reward dan Punishment Terhadap Peningkatan Disiplin Kerja Karyawan PT. Tunggal Perkasa Plantation-3 Kecamatan Sampoiniet Kabupaten Aceh Jaya. Serambi Akademica, Vol. IV, No. 1, ISSN : 2337 - 8085, 28-36.

Azwar, S. (2016). Metode Penelitian. Yogyakarta: Pustaka Pelajar.

Dachlan, U. (2014). Panduan Lengkap Structural Equation Modeling: Tingkat Dasar. Semarang: Lentera Ilmu.

Edirisooriyaa, W. A. (2014). Impact of Rewards on Employee Performance: With Special Reference to ElectriCo. International Conference on Management and Economics (pp. 311-318). Sri Lanka: Faculty of Management and Finance, University of Ruhuna.

Febrianti, S., Musadieq, M. A., \& Prasetya, A. (2014). Pengaruh Reward dan Punishment Terhadap Motivasi Kerja Serta Dampaknya Terhadap Kinerja (Studi pada Karyawan PT. Panin Bank Tbk. Area Mikro Jombang). Jurnal Administrasi Bisnis (JAB) Vol. 12 No. 1, 1-9.

Ghozali, I. (2008). Structural Equation Model Metode Alternatif dengan Partial Least Square (SEM-PLS). Semarang: Badan Penerbit Universitas Diponegoro.

Ghozali, I., \& Latan, H. (2015). Partial Least Squares : Konsep, Teknik dan Aplikasi Menggunakan SmartPLS 3.0 Edisi 2. Semarang: Badan Penerbit Universitas Diponegoro.

Hair, J., Hult, T., Ringle, C., \& Sartstedt, M. (2013). A Primer on Partial Least Squares Structural Equation Modeling (PLS-SEM). Los Angeles: Sage.

Handoko, H. T. (2012). Manajemen Personalia dan Sumber Daya Manusia, Edisi Kedua. Yogyakarta: BPFE.

Haryono, S. (2017). Metode SEM Untuk Penelitian Manajemen: AMOS, LISREL, \& PLS. Yogyakarta: PT. Luxima Metro Media.

Jamil, C. Z., \& Mohamed, R. (2013). The Effect of Management Control System on Performance Measurement Systems at Small Medium Hotel in Malaysia. International Journal of Trade, Economics and Finance, 202-208.

Jogiyanto, H. M. (2015). Partial Least Square (PLS) : Alternatif Structural Equation Modeling (SEM) dalam Penelitian Bisnis. Yogyakarta: Andi.

Karami, A., Dolatabadi, H. R., \& Rajaeepour, S. (2013). Analyzing the Effectiveness of Reward Management System on Employee Performance through the Mediating Role of Employee Motivation. International Journal of Academic Research in Business and Social Sciences. ISSN: 2222-6990, 327-338.

Mangkunegara, A. (2013). Manajemen Sumber Daya Manusia Perusahaan. Bandung: Remaja Rosdakarya.

Merchant, K. A., \& Stede, W. A. (2014). Sistem Pengendalian Manajemen ( Pengukuran Kinerja, Evaluasi, dan Insentif ). Jakarta: Salemba Empat. 


\section{National Conference of Creative Industry: \\ Sustainable Tourism Industry for Economic Development}

Universitas BundaMulia, Jakarta, 5-6 September 2018

e-ISSN No: 2622 - 7436

Merchant, K. A., \& Stede, W. A. (2016). Sistem Pengendalian Manajemen Pengukuran Kinerja, Evaluasi, dan Insentif. Jakarta: Salemba Empat.

Nazir. (2014). Metode Penelitian . Bogor: Ghalia Indonesia.

Nnaji-Ihedinmah, N., \& Egbunike, F. (2015). Effect of Rewards on Employee

Performance in Organizations: A Study of Selected Commercial Banks in Awka

Metropolis. European Journal of Business and Management.

Prabu, A. S., \& Wijayanti, D. T. (2016). Pengaruh Penghargaan dan Motivasi Terhadap Kinerja Karyawan (Studi Pada Divisi Penjualan PT. United Motors Center

Suzuki Ahmad Yani Surabaya). Jurnal Ekonomi Bisnis dan Kewirausahaan, Vol. 5, No. 2, 104-117.

Pratheepkanth, P. (2011). Capital Structure And Financial Performance: Evidence From Selected Business Companies In Colombo Stock Exchange Sri Lanka. Journal.

Purwanto, M. N. (2006). Ilmu Pendidikan Teoritis dan Praktis. Bandung: Remaja Rosdakarya.

Purwantono, I. (2014). Pengaruh Reward dan Punishment Terhadap Motivasi Kerja (Studi Kasus Pada Karyawan Kantor Pusat PT. Bakrie Telecom Tbk.). Jurnal Ilmiah Universitas Bakrie Vol.2 No.2.

Ratri, P. S., Abddurahman, D., \& Irfani, A. (2017). Pengaruh Reward dan Punishment terhadap Kinerja Karyawan pada Divisi Corporate Services PT.Inti (Persero) Bandung. Prosiding Manajemen (pp. 961-966). Bandung: Universitas Islam Bandung.

Shields, J. (2016). Managing Employee Performance and Reward, Second Edition. Cambridge University Press.

Sholihin, M., \& Ratmono, D. (2013). Analisis SEM-PLS dengan WarpPLS 3.0 untuk Hubungan Nonlinier dalam Penelitian Sosial dan Bisnis. Yogyakarta: CV ANDI OFFSET.

Suak, R., Adolfina, \& Uhing, Y. (2017). Pengaruh Reward dan Punishment Terhadap Kinerja Karyawan Sutanraja Hotel Amurang. Jurnal EMBA Vol.5 No.2, 10501059.

Sugiyono. (2012). Metode Penelitian Bisnis. Bandung: Alfabeta.

Sugiyono. (2016). Metode Penelitian Kuantitatif, Kualitatif dan R\&D. Bandung: Alfabeta.

Sujarweni, W. (2015). SPSS Untuk Penelitian. Yogyakarta: Pustaka Baru Press.

Sumarsan, T. (2013). Sistem Pengendalian Manajemen Konsep, Aplikasi dan Pengukuran Kinerja. Jakarta: Indeks Penerbit.

Sunarto, A., Rusilowati, U., \& Ciptaningsih, E. M. (2017). Pengaruh Reward (Penghargaan), Punishment (Hukuman) dan Kepuasan Kerja Terhadap Kinerja Karyawan Pada PT. Asuransi Sinar Mas Jakarta Pusat. Prosiding Seminar Ilmiah Nasional (pp. 392-411). Pamulang: Universitas Pamulang.

Suryadilaga, R. M., Musadieq, M. A., \& Nurtjahjono, G. E. (2016). Pengaruh Reward dan Punishment Terhadap Kinerja (Studi pada Karyawan PT Telkom Indonesia Witel Jatim Selatan Malang). Jurnal Administrasi Bisnis (JAB) Vol. 39 No.1, 156-163.

Suyadi, P. (2008). Manajemen Sumber Daya Manusia Kebijakan Kinerja Karyawan. Yogyakarta: BPFE.

Syahril, R. R., \& Nurbiyati, T. (2016). Pengaruh Reward Ekstrinsik dan Intrinsik Terhadap Kinerja Dengan Kepuasan Kerja Sebagai Variabel Intervening. Jurnal Riset Manajemen Vol. 3, No. 1, 23-27. 
Thompson, M. (2002). High Performance Work Organization in UK Aerospace, The Society of British Aerospace Companies, London. In M. Armstrong, $A$ Handbook of Human Resources Management Practice, 11 th ed. London: Kogan Page.

Widyanti, Y., \& Sari, S. (2014). Pengaruh Komunikasi Internal, Reward dan Punisment Terhadap Motivasi Kerja Karyawan di BPR Nur Semesta Indah Kencong Kabupaten Jember. Jurnal Ekonomi dan Bisnis. 